\title{
Undian Berhadiah Alfamart di Kota Bengkulu dalam Perspektif Ekonomi Syari'ah
}

\author{
Wahyu Abdul Jafar \\ Institut Agama Islam Negeri (IAIN) Bengkulu \\ wahyujabar@gmail.com
}

\begin{abstract}
This study aims to examine the issue of lucky draw that has been held by the management of Alfamart in the city of Bengkulu for the marketing interests of a produk. In order to reap maximum profits from consumers, the management of Alfamart in City of Bengkulu did not hesitate to give gifts to lucky consumers. But the problem is, sometimes this lucky draw still contains gambling (Maisyir). This research is included in the field research category, while in analyzing the data obtained, researchers use normative approaches. Data collection techniques used are interview techniques and documentation. After an in-depth study obtained a conclusion that law of the Alfamart lucky draw in the city of Bengkulu is divided into two, namely: First, the law is halal if the lucky draw is made into prizes without financial requirements to buy certain products or pay a certain amount of money. This gift is purely a form of ta'dbiman (Respect) or Mahabab (affection). The second, the law is haram, if the lucky draw uses a lottery system or gambling, that is, someone can take part in the lucky draw if you have purchased a certain produk or after paying money with a certain amount of money.
\end{abstract}

Keywords: Lottery, Gambling, Syari'ah Economy.

\begin{abstract}
Abstrak
Penelitian ini bertujuan untuk mengkaji persoalan undian berhadiah yang selama ini diadakan oleh pihak pengelola Alfamart Kota Bengkulu guna kepentingan marketing produk suatu barang. Demi meraup keuntungan yang maksimal dari konsumen, pihak pengelola Alfamart Kota Bengkulu tidak segan segan memberikan hadiah bagi konsumen yang beruntung. Namun yang menjadi problem, terkadang undian berhadiah ini masih mengandung unsur perjudian (Maisyir). Penelitian ini termasuk kategori penelitan lapangan, sedangkan dalam menganalisi data yang diperoleh, peneliti mengunakan pendeketan normatif. Teknik pengumpulan data yang dipergunakan adalah teknik wawancara dan dokumentasi. Setelah dilakukan kajian mendalam diperoleh sebuah kesimpulan bahwa hukum undian berhadiah di Alfamart Kota Bengkulu terbagi menjadi dua, yakni: Pertama, hukumnya halal jika undian berhadiah murni dijadikan hadiah tanpa ada persyaratan finansial harus membeli produk tertentu atau
\end{abstract}

Al-Istinbath : Jurnal Hukum Islam Vol. 4, No. 1, 2019; 1-14 p-issn: 2548-3374; e-issn: 2548-3382, DOI: 10.29240/jhi.v4i1.634

Available online at: http://journal.staincurup.ac.id/index.php/alistinbath 
membayar uang dengan kisaran besaran tertentu. Pemberian hadiah ini murni sebagai bentuk ta'dhiman (Penghormatan) atau mahabah (kasih sayang). Yang kedua, hukumnya haram, jika undian berhadiah mengunakan sistem lotre atau perjudian, yakni seseorang bisa mengikuti undian jika sudah membeli produk tertentu atau sesudah membayar uang dengan kisaran besaran tertentu.

Kata kunci: Undian Berhadiah, Judi, Ekonomi Syariah

\section{Pendahuluan}

Persoalan undian berhadiah merupakan persoalan yang hangat diperbicarakan dikalangan para ekonom muslim, selain karena undian berhadiah semakin banyak dipraktekan oleh para pedagang, ternyata praktek undian berhadiah dilapangan masih banyak menimbulkan berbagai persoalan, mulai dari status legalitas hukumnya sampai persoalan penipuan berkedok undian berhadiah. Namun walaupun undian berhadiah banyak menyisakan persoalan, masih sedikit penelitian yang sudah dipublikasikan di jurnal jurnal ilmiah terkait persoalan undian berhadiah. Salah satu penelitian yang sudah dipublikasikan dijurnal ilmiah adalah penelitian yang dilakukan oleh Bakhtiar dan Yusnanik dengan judul "Kejahatan Penipuan Dengan Modus Undian Berhadiah Ditinjau Secara Kriminologis"1. Penelitian ini berbeda dengan kajian yang akan peniliti kaji karena penelitian yang dilakukan oleh bakhtiar dan yusnanik hanya membahas modus penipuan yang berkedok undian berhadiah. Sedangkan penelitian yang penulis lakukan membahas persoalan legalitas hukum undian berhadiah ditinjau dari sisi fiqh-nya.

Salah satu penyebab undian berhadiah semakin marak dilakukan oleh pedagang adalah karena adanya persaingan ketat dalam dunia perdagangan yang sering kali memaksa setiap pebisnis untuk memutar otak agar barang dagangannya habis terjual dan mendapatkan keuntungan semaksimal mungkin. Salah satunya dengan strategi memberi undian berhadiah kepada konsumen. Hal seperti ini juga dilakukan oleh pihak pengelola Alfamart di Kota Bengkulu. Setiap konsumen yang membeli produk tertentu di Alfamart Kota Bengkulu akan diberikan kupon yang nanti kupon tersebut diundi dan pemenangnya mendapatkan hadiah tertentu. Promosi ini terbilang efektif untuk menarik minat pembeli. Tidak jarang calon pembeli yang akhirnya memutuskan untuk membeli barang dagangan karena tergiur dengan promisi hadiah yang melekat dibarang tersebut, apalagi bila hadiah yang dijanjikan memiliki nilai nominal yang banyak hinga mencapai jutaan rupiah. ${ }^{2}$

\footnotetext{
${ }^{1}$ Bakhtiar dan Yusnanik, Kejahatan Penipuan Dengan Modus Undian Berbadiah Ditinjau Secara Kriminologis, Jurnal Pasai Vol 7, No 2 (2013).

${ }^{2}$ Wawancara dengan bu Weny pelangan Alfamart, 23 Februari 2019
} 
Modus yang sering dipakai oleh pihak pengelola Alfamart di Kota Bengkulu ada beraneka ragam dalam memberikan hadiah kepada konsumen. Ada yang dengan strategi beli dua barang dapat bonus satu barang. Ada yang memberikan kupon untuk pembelian produk tertentu kemudian kupon tersebut diundi. Pemenang dari undian tersebutlah yang kemudian diberi hadiah. Ada juga modus memberikan point tertentu yang bisa ditukarkan dengan produk barang tertentu jika point nya sudah mencukupi target. ${ }^{3}$

Menghadapi fenomena diatas fiqh perlu angkat bicara untuk menghukumi apakah praktek undian berhadiah sebagai strategi marketing yang dilakukan oleh pihak pengelola Alfamart di Kota Bengkulu, guna menarik minat pembeli sudah diperbolehkan dalam ekonomi Islam, mengingat jual beli harus dilakukan atas dasar kerelaan tanpa merugikan salah satu pihak. Adapun pendekatan yang penulis gunakan dalam penelitian ini adalah dengan pendekatan ekonomi syari'ah. Jika undian berhadiah yang dilakukan hanya merugikan konsumen dengan cara hadiah yang diberikan sebenarnya dibebankan kepada seluruh konsumen yang membeli produk tersebut tentu undian berhadiah semacam ini hanya akal akalan pihak pengelola saja atau memang hadiah yang diberikan merupakan bentuk penghargaan atas loyalitas konsumen karena sudah membeli produk tersebut. Disini perlu sekali hadirnya fiqh untuk memberikan kepastian legalitas hukum agar konsumen tidak selalu menjadi pihak yang dirugikan terus. Fiqh perlu hadir untuk menjelaskan bentuk bentuk undian berhadiah yang diperbolehkan dan bentuk bentuk yang dilarang dalam ekonomi Islam. Untuk memperoleh jawaban dari pertanyaan ini dibutuhkan penjelasan beberapa hal sebagai berikut.

\section{Pembahasan}

\section{Pengertian Undian Berhadiah}

Kata undian dalam Kamus Besar Bahasa Indonesia berarti sesuatu yang diundi (lotre). Istilah lotre sendiri berasal dari bahasa belanda "loterij" yang memiliki arti undian berhadiah, nasib, peruntungan. Sedangkan dalam bahasa inggris istilah lotre berasal dari kata "lottery" yang berarti undian. ${ }^{4}$

Dalam bahasa arab istilah undian dikenal dengan istilah qur'ah, yang bisa dimaknai sebagai upaya memilih sebagian pilihan (alternatif) dari keseluruhan pilihan yang tersedia dengan cara sedemikian rupa sehingga setiap pilihan yang tersedia itu memiliki kemungkinan (probabilitas) yang sama besarnya untuk terpilih. Undian merupakan upaya paling mampu menjauhkan unsur

\footnotetext{
${ }^{3}$ Wawancara dengan Sarah pelayan Alfamart, 23 Februari 2019

${ }^{4}$ Safiudin Shidik, Hukum Islam Tentang Berbagai Persoalan Kontemporer, (Jakarta: PT Intimedia Cipta Nusantara, 2004), Cet. ke-1, h. 379
} 
keberpihakan dalam memilih dan dapat dilakukan untuk maksud-maksud yang jauh sama sekali dari perjudian. ${ }^{5}$

Istilah undian memiliki persamaan baik dalam bahasa Indonesia, bahasa Belanda, bahasa Inggris maupun dalam bahasa Arab, yakni sama sama mengandung unsur untung-untungan (spekulatif) yang memiliki konsekuensi tertentu bagi orang-orang yang melakukan undian. Dari sini dapat diketahui bahwa istilah undian bersinonim dengan pengertian lotre, di mana dalam lotre ada unsur spekulatif. Namun faktanya, di masyarakat kata undian dan lotre pengertiannya dibedakan, sehingga hukumnya pun berbeda. Asumsi masyarakat undian pasti halal sedangkan lotre pasti haram, hal ini karena menurut asumsi masyarakat dalam undian tidak ada pihak yang merasa dirugikan. Sedangkan dalam lotre pasti ada pihak yang dirugikan. ${ }^{6}$

Istilah undian berhadiah yang terdapat pada penjualan produk tertentu dipergunakan untuk undian-undian yang dikolaborasikan dengan semacam pemberian hadiah bagi konsumen yang menjadi pemenang baik dengan beberapa persyaratan tertentu maupun tanpa ada syarat sama sekali.

\section{Pembagian Undian Berhadiah Dalam Fiqh}

Imam Hanafi, Maliki, Hambali dan Syafi'i membagi Undian berhadiah menjadi dua macam jika ditinjau dari sudut manfaat dan mudarat-nya, yaitu: ${ }^{7}$

1. Undian yang tidak mengandung mudarat (tidak mengakibatkan kerugian)

Undian yang tidak mengandung mudarat (tidak mengakibatkan kerugian) bagi pihak manapun, baik bagi pihak yang diundi maupun bagi peserta lain yang mengikuti undian. Pemenang undian ini berhasil mendapatkan hadiah tanpa menyebabkan kerugian bagi peserta lain yang mengikuti undian. Pemenang undian hanya mendapatkan keuntungan berupa hadiah di satu pihak dan pihak lain tidak mendapat apa apa (hadiah), namun peserta undian yang tidak mendapatkan hadiah tidak juga mendapatkan kerugian secara finansial, yang termasuk dalam kategori undian ini adalah segala macam undian berhadiah dari perusahaan-perusahaan dengan motif promosi atas barang produksinya (tanpa ada persyaratan tertentu baik harus membeli produk tertentu atau ada persyaratan yang lain), undian untuk mendapatkan peluang tertentu (karena terbatasnya peluang tersebut) seperti undian untuk berangkat menunaikan ibadah haji dengan Cuma-cuma dan undian untuk menentukan giliran tertentu, seperti dalam arisan. Termasuk juga dalam kategori undian yang tidak

${ }^{5}$ Abdul Azis Dahlan, et al., Ensiklopedi Hukum Islam, Jakarta: Ichtiar Baru van Hoeve, 1997), Cet. ke-1, h. 1869

${ }^{6}$ Saifudin Shidik, Hukum Islam Tentang Berbagai Persoalan Kontemporer, Jakarta : PT Intimedia Cipta Nusantara, 2004), Cet. ke-1, h. 379-380

${ }^{7}$ Abdul Azis Dahlan, et al., Ensiklopedi Hukum Islam, Jakarta: Ichtiar Baru van Hoeve, 1997), Cet. ke-1, h. 1869. 
mengandung mudhorot adalah bentuk undian dalam kategori prioritas urutan dalam perlombaan, baik olahraga maupun kesenian. ${ }^{8}$

2. Undian yang mengandung unsur mudarat (mengakibatkan kerugian)

Undian yang mengandung unsur mudarat (kerusakan) jika diperinci secara detail terbagi menjadi dua juga, yakni:

a. Undian yang menimbulkan kerugian secara finansial bagi pihak-pihak yang diundi. Hal ini terjadi karena antara pihak-pihak yang diundi terdapat unsurunsur untung-rugi (spekulatif), yakni jika di satu pihak ada yang mendapat keuntungan, maka di pihak lain ada yang mendapatkan kerugian. Antara keuntungan yang didapatkan dengan kerugian yang diderita akibat praktek undian ini jauh lebih besar kerugiannya karena biasanya yang mendapatkan hadiah hanya satu orang atau beberapa orang tertentu saja, sedangkan yang tidak mendapat hadiah jumlahnya jauh lebih banyak, bisa puluhan, ratusan hinga ribuan orang. ${ }^{9}$ Undian yang terdapat unsur-unsur ini dalam Alquran disebut al-maisir ${ }^{10}$.

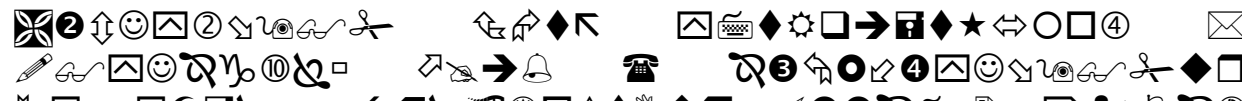

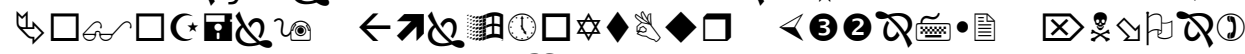
IId है

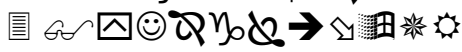
"Mereka bertanya kepadamu tentang khamar dan judi. Katakanlah: "Pada keduanya (khomr dan judi) terdapat dosa yang besar dan beberapa manfaat bagi manusia, tetapi dosa keduanya (khomr dan judi) lebih besar dari manfaatnya". (QS Al-Baqarah: 219)

b. Undian yang hanya menimbulkan dampak kerugian atau kerusakan bagi pelakunya sendiri, yaitu berupa kerusakan mental. Kerusakan mental ini muncul karena manusia menggantungkan nasib, rencana, pilihan dan aktivitasnya kepada para "pengundi nasib" atau "peramal", sehingga akal pikiran manusia menjadi labil, kurang percaya diri dan terkadang berpikir tidak realistis. Undian semacam ini dalam Alquran disebut dengan istilah aląlam (QS Al-Maa'idah: 90).

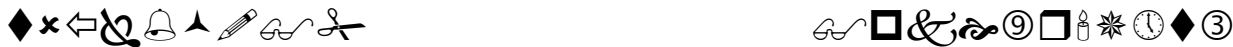

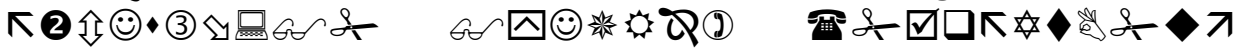

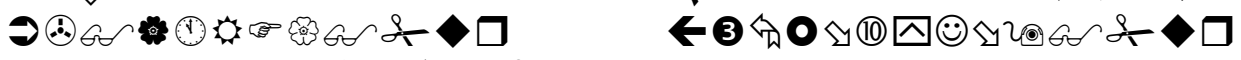

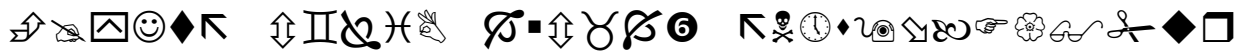

8 Abdul Azis Dahlan, et al., Ensiklopedi Hukum Islam, Jakarta: Ichtiar Baru van Hoeve, 1997), Cet. ke-1, h. 1869-1870.

9 Abdul Azis Dahlan, et al., Ensiklopedi Hukum Islam, Jakarta: Ichtiar Baru van Hoeve, 1997), Cet. ke-1, h. 1869

10 A. Hamid Sarong, Ridha Hidayatullah, Dahlan Ali, Efektivitas Penerapan Hukuman Terbadap Pelaku Tindak Pidana Maisir Dalam Qanun Nomor 6 Tabun 2014, Syiah Kuala Law Journal : Vol. 1, No.3 Desember 2017. 


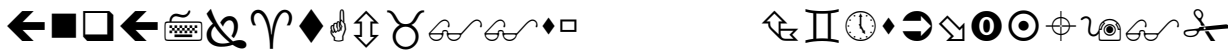

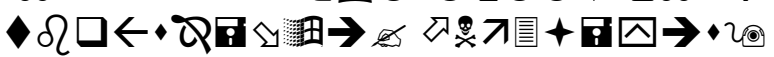

Hai orang-orang yang beriman, sesunggubnya (meminum) khamar, berjudi, (berkorban untuk) berhala, mengundi nasib dengan panah, adalab termasuk perbuatan syaitan. Maka jaubilah perbuatan-perbuatan itu agar kamu mendapat keberuntungan. (QS. AlMaidah: 90)

\section{Program undian berhadiah Alfamart di Kota Bengkulu}

Program undian berhadiah Alfamart ini merupakan kerjasama Alfamart dengan berbagai merchant atau brand ternama di Indonesia. Ketentuan untuk mengikuti undian berhadiah Alfamart beragam tergantung dari kebijakan brand yang bersangkutan. Umumnya, Anda diharuskan untuk membeli produk dalam jumlah tertentu kemudian akan mendapatkan kode unik di kartu belanja. Selanjutnya, kode unik tersebut bisa dimasukkan melalui situs Alfamart di bagian submit struck. Ada kolom nama program undian berhadiah, kemudian nama dan alamat email Anda, kota asal, nomor handphone, kemudian nomor transaksi dan kode yang tertera di struk belanja. Setelah semua terisi, Anda tinggal menekan tombol 'submit' yang ada di bagian bawah.

Setelah selesai di bagian submit struck, Anda bisa melakukan cek poin untuk mengetahui berapa jumlah poin yang sudah dikumpulkan. Untuk melakukan cek poin, pilih program undian berhadiah Alfamart kemudian masukkan nomor handphone Anda. Setelah itu, klik tombol 'lihat' untuk mengetahui jumlah poin yang sudah Anda kumpulkan. Selain program undian berhadiah, biasanya banyak pula kuis produk Alfamart yang juga menawarkan hadiah beragam. Baik program undian berhadiah maupun kuis produk Alfamart ini memiliki masa tertentu dan pengundian akan dilakukan di akhir periode promosi. ${ }^{11}$

Untuk lebih detailnya, undian berhadiah alfamart 2019 bisa dilihat pada gambar dibawah ini.

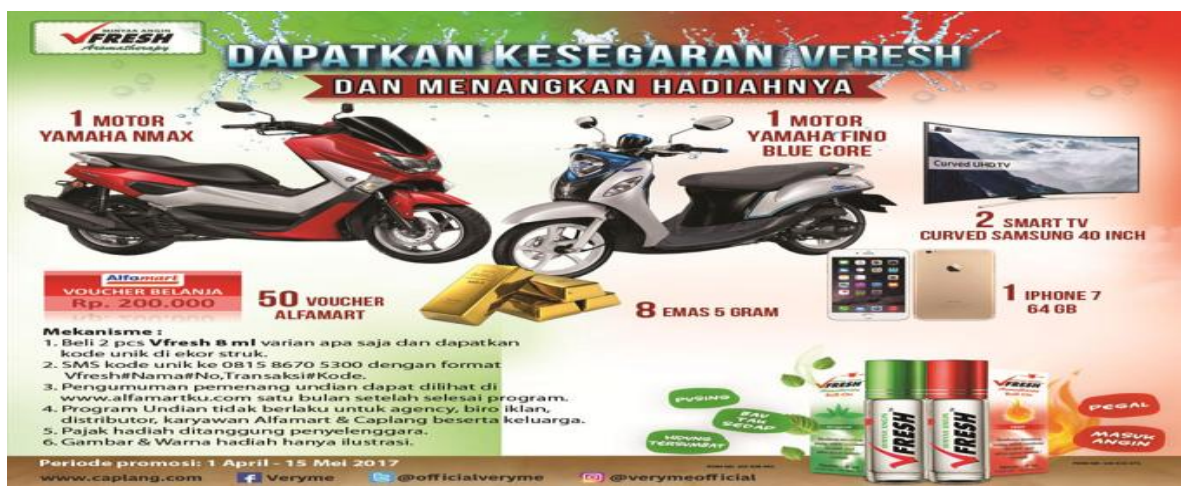

${ }^{11}$ Didownloud dari http://alfamartku.com/undian-berhadiah pada tanggal 25 Februari 
Gambar : alfamartku.com

\section{Analisis Undian Berhadiah Alfamart Di Kota Bengkulu Dalam Perspektif Fiqh}

Untuk mengetahui hukum problem undian berhadiah Alfamart di Kota Bengkulu perlu diketahui terlebih dulu beberapa dalil yang dijadikan bujjah dalam beristinbath, antara lain: pertama, Surat al-Baqarah ayat 219 sebagaimana di atas. Dalam ayat tersebut Allah SWT. menjelaskan bahwa khamar dan perjudian memang masih ada manfaat yang bisa diambil ${ }^{12}$, namun dosa (bahaya) yang terkandung didalamnya jauh lebih banyak berbahaya ketimbang manfaat yang terdapat didalamnya. Akhir akhir ini, banyak orang yang menjadikan perjuadian bagian dari mata pencaharian dan tidak sedikit juga yang mengkolaborasikan antara judi dan perdagangan dengan alasan marketing. Namun, apapun alasannya, Allah SWT. sudah menegaskan bahwa semua manfaat dalam bentuk apapun yang berasal dari perjudian masih lebih banyak lagi mudarat atau bahayanya.

Penyebutan lafadz khamr dan judi (maisir) secara bergandengan pada ayat 219 di atas disebabkan keduanya banyak menimbulkan persengketaan, cacimencaci, dan kata-kata yang tidak senonoh, (dan beberapa manfaat bagi manusia) dengan meminum-minuman keras akan menimbulkan rasa senang (di luar kontrol), dan dengan berjudi akan mendapatkan uang (dengan jalan menzalimi orang lain), dan dosa keduanya atau bencana-bencana yang timbul sangat buruk daripada manfaatnya ${ }^{13}$ yang memperoleh manfaat dari perjuadian hanya orang yang menang taruhan saja sedangkan peserta judi yang lain mendapatkan kerugian secara finansial oleh karena itu, Alquran menyebut judi mudarat dan dosanya lebih banyak ketimbang manfaat yang ada didalamnya. Dalil selanjutnya adalah Surat al-Maidah ayat 3,

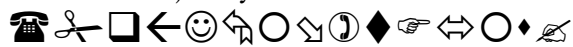

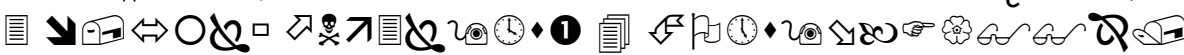

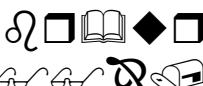

12 Asbabun nuzul ayat ini adalah ketika Rasulullah s.a.w. mendatangi kota Madinah sedangkan mereka (penduduk Madinah) dalam keadaan meminum minuman keras (khomer) dan memakan hasil judi, lantas mereka menanyakan perihal kedua perkara ini kepada Rasulullah s.a.w. maka turunlah ayat tersebut. Lalu mereka berkata: "Hal itu tidak diharamkan kepada kita", Ia sesungguhnya berfirman "(adalah) dosa yang besar", dan mereka pun meminum khomer hingga suatu ketika salah satu kaum muhajirin sholat dan mengimami sholat maghrib lalu berbuat kesalahan dalam bacaan sholatnya, maka Allah s.w.t. menurunkan ayat yang lebih tegas

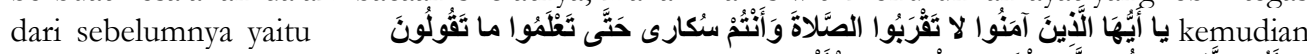

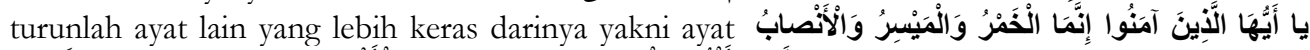

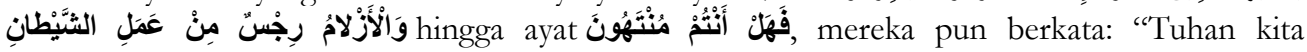
(sungguh) telah melarang kita”. al-Maroghy, Tafsir Al-Maroghiy, Maktabah Syamilah 14 G, Juz 2, h. 138

13 Di downlod dari : https://www.bacaanmadani.com/ pada tanggal 20 Desember 
Dan (diharamkan juga) mengundi nasib dengan anak panah, (mengundi nasib dengan anak. panah itu) adalah kefasikan

Bentuk tunggal dari ąlam ialah zulam, tetapi adakalanya dibaca zalam. Dahulu di masa Jahiliah orang-orang Arab sering mempraktekan zalam ini. Azlam sebenarnya merupakan tiga buah anak panah, pada salah satunya bertuliskan kata 'lakukanlah', pada yang kedua bertuliskan 'jangan kamu lakukan', sedangkan pada yang ketiganya tidak terdapat tulisan apa pun. Jika anak panah tersebut telah dikocok, lalu keluar panah yang bertuliskan kata perintah, maka orang yang bersangkutan mengerjakannya; atau jika yang keluar kata larangan, maka ia meninggalkannya. Jika yang keluar adalah anak panah yang kosong, maka ia mengulanginya lagi. Sedangkan istilah istiqsam diambil dari makna meminta bagian dari anak-anak panah tersebut yang dipakai untuk mengundi. Dahulu orang-orang Arab adakalanya memakai aə̧lam untuk beristikharah dan adakalanya untuk berjudi. Allah SWT. mengharamkan perbuatan mengundi nasib semacam ini karena perbuatan tersebut akan mengakibatkan kefasikan, kesesatan, kebodohan, dan kemusyrikan. Allah Swt. telah memerintahkan apabila ada keraguan dalam urusan dunia ini maka hendaknya melakukan istikharah untuk meminta petunjuk kepada-Nya tentang perkara yang terbaik untuk dilakukan. ${ }^{14}$

Dalil selanjutnya adalah Surat Al-Maidah ayat 90-91

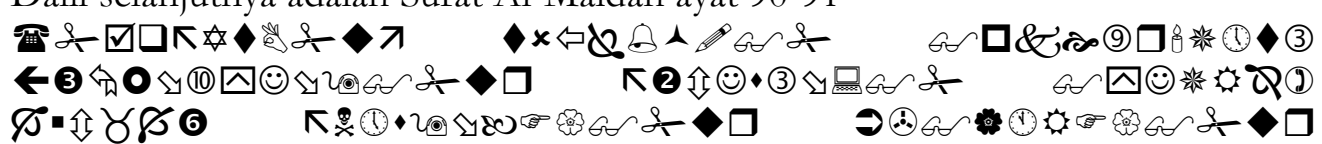

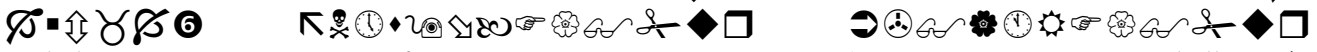

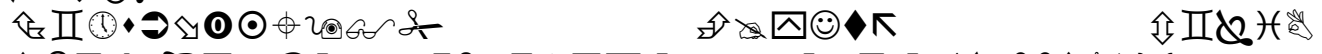

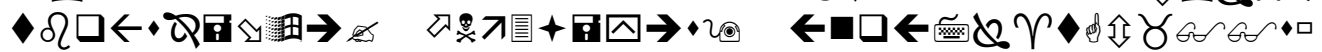

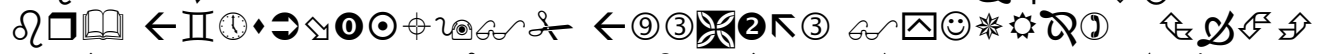

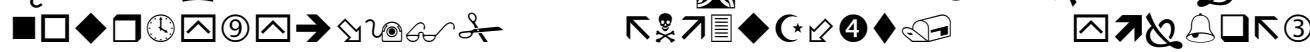

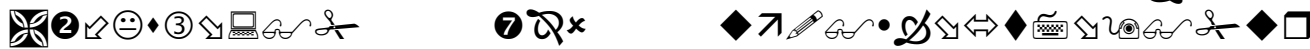

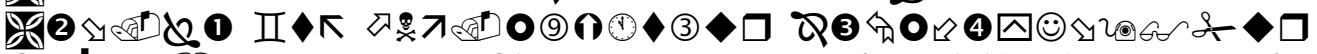

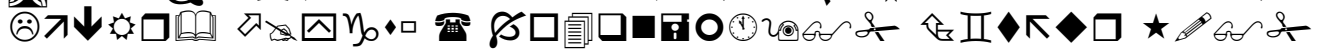

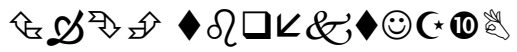
Hai orang-orang yang beriman, sesunggubnya (meminum) khamar, berjudi, berkorban untuk.) berhala, mengundi nasib dengan panah, adalab Termasuk perbuatan syaitan. Maka jaubilab perbuatan-perbuatan itu agar kamu mendapat keberuntungan. Sesunggubnya syaitan itu bermaksud hendak menimbulkan permusuban dan kebencian di antara kamu lantaran (meminum) khamar dan berjudi itu, dan menghalangi kamu dari mengingat Allah dan sembahyang; maka berhentilah kamu (dari mengerjakan pekerjaan itu).

Kata وَالْمَيْسِر memiliki arti berjudi atau taruhan. ${ }^{15}$ Kata (ميسر ) maysir berasal dari kata (يسر) yusr yang berarti mudah. Oleh karena inilah

\footnotetext{
${ }^{14}$ Ibnu Katsir, Tafsir Ibnu Katsir, Maktabah Syamilah 14 G, Juz 3, h. 24

${ }^{15}$ Imam Jalaluddin Al-mahalli dan Imam Jalaluddin As-suyuti, Tafsir Jalalain, (Bandung: Sinar Baru Algesindo, 2009), h. 470
} 
dinamai maysir karena pelakunya memperoleh harta dengan mudah, kehilangan harta dengan mudah. Kata ini juga berarti pemotongan dan pembagian. Dahulu masyarakat Jahiliah berjudi dengan unta untuk kemudian mereka potong dan mereka bagi-bagikan dagingnya sesuai kemenangan yang mereka raih. ${ }^{16}$

Mohamad Ali al-Shabuni, penulis Tafsir Ruhul Ma'ani berpendapat bahwa segala macam perjudian, seperti dadu, catur dan lain sebagainya termasuk kategori maisir. ${ }^{17}$ Namun, Imam Syafi'i memiliki pendapat sedikit berbeda mengenai permainan catur: "apabila permainan catur itu dilakukan tanpa ada taruhan, tanpa omongan yang jorok dan tanpa melalaikan shalat, maka tidaklah haram dan tidak termasuk maisir."

Quraish Shihab dalam tafsirnya Al-mishbah menjelaskan bahwa yang dimaksud dengan maysir/ judi adalah segala macam aktifitas yang dilakukan oleh dua pihak atau lebih untuk memenangkan suatu pilihan dengan menggunakan uang atau materi sebagai taruhan. ${ }^{19}$ Dari sini jelas bahwa maysir dilarang karena kerusakan yang ditimbulkannya.

Judi diharamkan karena mengandung kerusakan yang besar, meskipun ada sedikit manfaatnya. Sumber awal kerusakan dalam judi adalah angan-angan pada keuntungan besar, padahal yang diperoleh hanya kerugian dan kehancuran. Oleh karena itu, berlaku suatu kaidah yang memandang perlu menghambat terjadinya kerusakan (sadd azzari'ah) yaitu : dar 'al-mafaasid muqaddam 'alaa jalb almashaalih (menghindari kerusakan harus didahulukan daripada menarik kemaslahatan). Kerusakan yang akan ditimbulkannya harus dihambat atau ditutup, sehingga tidak akan timbul kerusakan-kerusakan lainnya yang jauh lebih besar. ${ }^{20}$

Untuk undian berhadiah di Alfamart yang tidak mengandung kerusakan sama sekali atau bahkan mengandung manfaat, seperti undian berhadiah point yang dalam jumlah tertentu bisa ditukarkan produc tertentu, Islam membolehkannya. Hal ini sebagaimana pernah dilakukan Rasulullah SAW sendiri ketika mengundi istri-istrinya untuk menentukan siapa yang lebih berhak ikut bersamanya ketika berpergian,

${ }_{16}$ M.Quraish Shihab, Tafsir Al-mishbah, (Jakarta : Lentera Hati, 2002), hlm. 192-193

17 Akhir-akhir ini berbagai jenis judi ada banyak dengan ragam varian yang beraneka ragam dalam kehidupan masyarakat sehari-hari, baik yang bersifat terang-terangan maupun secara sembunyi-sembunyi. Ali Geno Berutu, Implementasi Qanun Maisir (Judi) Terbadap Masyarakat Suku Pak-Pak Di Kota Subulussalam Aceh, Jurnal Aristo Vol. 4 No. 2 Juli 2016, diakses pada tanggal 9 Februari 2019

${ }^{18}$ Muhammad Ali Ash-Shabuni, Rawai'ul Bayan: Tafsir Ayat-Ayat Hukum, (Semarang: CV. Asy-syifa, 1994), h. 440-441

${ }^{19}$ M.quraish shihab, Tafsir Al-mishbah, (Jakarta : Lentera Hati, 2002), h. 192-193

${ }^{20}$ Abdul Azis Dahlan, et al., Ensiklopedi Hukum Islam, Jakarta: Ichtiar Baru van Hoeve, 1997), Cet. ke-1, h. 1871. 


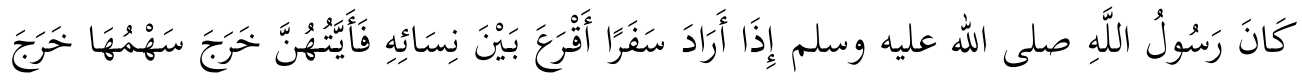

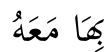

Apabila Rasulullah Shallallabu 'alaibi wa sallam hendak safar, beliau mengundi diantara istrinya. Siapa yang namanya keluar, beliau akan berangkat bersama istrinnya yang menang. (HR. Bukhari) ${ }^{21}$

Menurut Ibrahim Hosen undian yang dilarang oleh syara' ialah undian sejenis azlam yang merupakan upaya untuk dapat mengetahui sesuatu yang sifatnya ghaib yang hanya dimiliki oleh Allah SWT. yang dilakukan dengan cara mengundi anak panah. Dalam undian semacam ini terdapat perbuatan syirik (menyekutukan Allah) yang merupakan dosa besar dalam Islam . Termasuk hal ini adalah ramalan yang ada di pinggir pinggir jalan yang dimaksudkan untuk mengetahui nasib dan masa depan seseorang. Hal senada juga diungkapkan oleh Umar Hubeis, Syekh Ahmad Sukatti, Fuad Mohd. Fachruddin dan sebagainya. ${ }^{22}$

Dalam menyikapi permasalahan undian berhadiah, Syek Yusuf Qardhawi, Pakar Hukum Islam kontemporer yang fatwanya masih dipakai hinga saat ini, membagi bentuk-bentuk hadiah menjadi tiga bentuk, yaitu:

\section{Bentuk undian berhadiah yang diperbolehkan Syariat}

Bentuk hadiah yang diperbolehkan dan diterima oleh syara' adalah hadiah yang ditujukan untuk memberikan memotivasi dan mengajak kepada peningkatan ilmu pengetahuan yang bermanfaat dan serta mendorong amal shaleh. Misalnya, hadiah yang disediakan bagi pemenang dalam perlombaan menghafal Alquran atau hadiah yang disiapkan bagi yang berprestasi dalam studi.

Bisa juga berupa hadiah sumbangan dalam bidang keIslaman, keilmuan, sastra atau sejenisnya yang disediakan oleh pemerintah, yayasan dan individu. Semua itu diperbolehkan asalkan berfungsi untuk memotivasi dalam persaingan yang diperbolehkan syara' dalam kebaikan. ${ }^{23}$

Dalam hadits riwayat Ahmad dari Ibnu Umar disebutkan bahwa Nabi Muhammad pernah melaksanakan perlombaan balap kuda. Kemudian Nabi memberikan hadiah kepada para pemenangnya.

\footnotetext{
${ }^{21}$ Imam Bukhori, Shobih Bukhori, Maktabah Syamilah, Juz 2, h.916

22 Abdul Azis Dahlan, et al., Ensiklopedi Hukum Islam, (Jakarta: Ichtiar Baru van Hoeve, 1997), Cet. ke-1, h. 1871

${ }^{23}$ Yusuf Qardhawi, Min Hadyul Islam Fatawi Muashirah, (Al-Manshurah: Daarul Wafaa', 1994), Cet. ke-3, h.499
} 


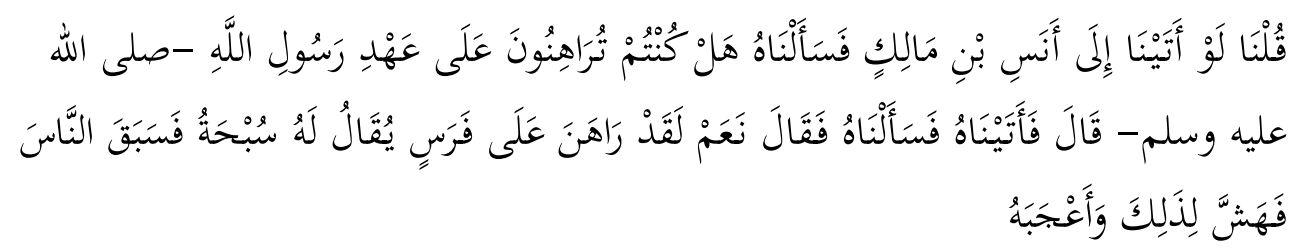

Dari Anas bin Malik r.a, ketika ia ditanya, "Pernabkan kamu mengadakan lomba di masa Rasulullah dengan menyediakan hadiah/tanggungan?" Jawab Annas : 'Ya benar, Rasulullah SAW menyediakan kuda balapnya untuk hadiah, dan ketika ada salah seorang yang menang, maka beliau tersenyum merasa senang dan keheran-heranan." (HR Ahmad). ${ }^{24}$

Kategori undian berhadiah pada alfamart di kota bengkulu adalah undian dengan sistem beli dua produk barang dapat bonus satu barang. Misal beli sabun lux dua buah gratis sampo saset clear.

\section{Bentuk Undian Berhadiah yang Diharamkan Syariat tanpa Adanya Perselisihan}

Bentuk undian berhadiah yang tidak diragukan keharamannya adalah jika orang yang membeli kupon dengan harga tertentu, banyak atau sedikit, tanpa ada gantinya melainkan hanya untuk ikut serta dalam memperoleh hadiah yang disediakan berupa mobil, emas, atau lainnya maka hal seperti ini termasuk yang dilarangan (bagi yang melakukannya dianggap telah melakukan dosa besar). Karena termasuk perbuatan judi yang dirangkaikan dengan khamar seperti disebut dalam QS Al-Baqarah ayat 219 dan QS Al-Maa'idah ayat 90.

Para ulama' berkata, "Perumpamaan orang yang memperoleh harta dari jalan haram, lalu menyedekahkannya ke jalan Allah bagaikan orang yang membersihkan najis dengan air kencing, maka hanya akan menambahnya lebih kotor." Yang termasuk kategori ini dalam undian berhadiah pada alfamart di kota bengkulu adalah undian dengan sistem beli kupon untuk dapat hadian tertentu.

\section{Bentuk Undian Berhadiah yang Masih diperselisihkan Hukumnya}

Bentuk undian berhadiah yang masih diperselisihkan hukumnya adalah berupa kupon yang diberikan kepada seseorang sebagai ganti dari pembelian barang dari sebuah toko atau karena membeli bensin di sebuah pom bensin. Juga karena mengikuti pertandingan bola dengan membayar tiket masuk disertai dengan pemberian kupon. Namun dikecualikan dari hal ini, orang yang membeli barang dari toko atau perusahaan hanya dengan motivasi ingin mendapatkan hadiah, sedang ia tidak punya tujuan (keperluan) untuk membelinya. Maka hal ini mengarah kepada judi yang terlarang atau mendekatinya. 
Meskipun Yusuf Qardhawi sendiri tidak suka jika perusahaanperusahaan Islam ikut-ikutan menggunakan cara Barat ini dalam menarik pelanggan, misalnya dengan membagi-bagikan hadiah yang hakikatnya masih samar bagi kebanyakan pedagang pada zaman sekarang. Sebab hadiah-hadiah yang dibagikan kepada sebagian pembeli itu pada akhirnya menimbulkan kenaikan harga yang notabeneih harus ditanggung oleh semua pembeli. Dengan demikian, seolah-olah pembeli yang beruntung mendapatkan hadiah memungut harganya dari seluruh pembeli. Hal inilah yang menimbulkan kesamaran (syubbat) menurut pandangan Yusuf Qardhawi, walaupun sebagian pedagang (produsen) beralasan bahwa hadiah yang diberikan itu diambilkan dari laba atau keuntungannya. ${ }^{25}$

Dalam hal ini sebenarnya menurut Qardhawi masih perlu diteliti lebih lanjut. Bagaimanapun juga, Yusuf Qardhawi tidak memandang terlarang menerima hadiah tersebut asalkan tujuan pokoknya adalah membeli. Namun, pada kitab yang sama juz III Yusuf Qardhawi mendukung pendapat Sheikh Abdul Aziz bin Baz (Mufti Arab Saudi) yang cenderung mengharamkan bentuk semacam ini. ${ }^{26}$

\section{Penutup}

Hukum undian berhadiah alfamart di kota bengkulu terbagi menjadi dua macam. Pertama, hukumnya halal jika undian berhadiah murni dijadikan hadiah tanpa ada persyaratan finansial harus membeli produk tertentu atau membayar uang dengan besaran tertentu. Pemberian hadiah ini murni sebagai bentuk ta'dhiman (penghormatan) atau Mahabah (kasih sayang). Kedua, hukumnya haram, jika undian berhadiah mengunakan sistem lotre atau perjudian, yakni seseorang bisa mengikuti undian jika sudah membeli produk tertentu atau sesudah membayar uang tertentu, hal ini mirip seperti praktek lotre yang mensyaratkan pembeli untuk membayar kupon tertentu agar bisa mengikuti undian, jika tidak membayar maka tidak bisa mengikuti undian. Oleh karena itu, hukum undian berhadiah dengan sistem seperti ini pada hakekatnya sama dengan lotre dan perjudian. Sebab hadiah-hadiah yang dibagikan kepada sebagian pembeli itu pada akhirnya menimbulkan kenaikan harga yang harus ditanggung

${ }^{25}$ Yusuf Qardhawi, Min Hadyul Islam Fatawi Muashirah, (Al-Manshurah: Daarul Wafaa', 1994), Cet. ke-3, h.499

26 Mengenai undian berhadiah (bentuk yang masih diperselesihkan) dari perusahaan dagang atau produsen, yusuf Qardhawi juga menyatakan bahwa hal tersebut adalah haram meskipun pada awalnya beliau cenderung membolehkan. Adapun yang menjadi sebab keharamannya antara lain sebagai berikut: 1. Mengandung motif perjudian, yakni bergantung pada nasib bukan pada usaha yang merupakan sunatullah. 2. Menimbulkan watak egoisme dalam diri manusia. 3. Nilai hadiah yang besar tersebut sebenarnya diambil dan pengumpulan uang konsumen sendiri. 4. Menjadikan konsumen bersifat pemboros. Hasil penelitian Sulaiman mahasiswa IAIMNU metro yang berjudul "Studi Analisis Pendapat Yusuf Qardhawi Tentang Undian Berhadiah", lulus tahun 2014 
oleh semua pembeli. Dengan demikian, seolah-olah pembeli yang beruntung mendapatkan hadiah memungut harganya dari seluruh pembeli.

\section{Daftar Pustaka}

A. Hamid Sarong, Ridha Hidayatullah, Dahlan Ali, Efektivitas Penerapan Hukuman Terhadap Pelaku Tindak Pidana Maisir Dalam Qanun Nomor 6 Tahun 2014, Syiah Kuala Law Journal: Vol. 1, No.3 Desember 2017.

Al-Maroghy, Tafsir Al-Marogbiy, Maktabah Syamilah 14 G, Juz 2

Berutu, Ali Geno, Implementasi Qanun Maisir (Judi) Terbadap Masyarakat Suku PakPak. Di Kota Subulussalam Aceh, Jurnal Aristo Vol. 4 No. 2 Juli 2016

Bakhtiar dan Yusnanik, Kejahatan Penipuan Dengan Modus Undian Berhadiah Ditinjan Secara Kriminologis, Jurnal Pasai Vol 7, No 2 (2013)

Dahlan, Abdul Azis, et al., Ensiklopedi Hukum Islam , Jakarta: Ichtiar Baru van Hoeve, 1997

Ibnu Katsir, Tafsir Ibnu Katsir, Maktabah Syamilah 14 G, Juz 3

Imam Ahmad Bin Hambal, Musnad Imam Ahmad, Maktabah Syamilah, Jus 26

Imam Bukhori, Shobih Bukhori, Maktabah Syamilah, Juz 2

Imam Jalaluddin Al-mahalli dan Imam Jalaluddin As-suyuti, Tafsir Jalalain, Bandung: Sinar Baru Algesindo, 2009

Imam Muslim, Shobih Muslim, Maktabah Syamilah 14 G Imam Suyuti, Asbah wa nadhoir, Maktabah Syamilah 14 G, Jus 1

Koenta Adji Koerniawan, Prinsip-Prinsip Dasar Ekonomi Islam Dan Pengarub Terbadap Penetapan Standar Akuntansi, Jurnal Modernisasi, Volume 8, Nomor 1, Februari 2012

M.quraish shihab, Tafsir Al-mishbah, Jakarta : Lentera Hati, 2002

Muhammad Ali Ash-shabuni, Rawai'ul Bayan: Tafsir ayat-ayat bukum, Semarang: CV. Asy-syifa, 1994

Mursal, Implementasi Prinsip-Prinsip Ekonomi Syariah: Alternatif Mewnjudkan Kesejabteraan Berkeadilan, Jurnal Perspektif Ekonomi Darussalam, Volume 1 Nomor 1, Maret 2015, ISSN. 2502-6976.

Safiudin Shidik, Hukum Islam Tentang Berbagai Persoalan Kontemporer, Jakarta: PT Intimedia Cipta Nusantara, 2004

Sohrah, Prinsip Ekonomi Dalam Islam, Jurnal Al-Qadāu Volume 1 Nomor 2/2014, diakses pada tanggal 9 Februari 2019

Sulaiman, IAIMNU Metro "Studi Analisis Pendapat Yusuf Qardhawi Tentang Undian Berbadiab”, 2014 
Sugeng, Anggoro, Analisis Prinsip Ekonomi Islam Terhadap Operasional Produk Investasi Emas Pada Perbankan Syariah, Jurnal Ekonomi Islam La_Riba Volume VI, No. 2, Desember 2012

Yusuf Qardhawi, Min Hadyul Islam Fatawi Muashirah, (Al-Manshurah: Daarul Wafaa', 1994), Cet. ke-3

Zainuddin, Cholidi dan Heri Junaidi, Prinsip-Prinsip Ekonomi Islam: Sebuah Kajian Awal, Jurnal Muamalah, Vo 1.3, No. 1, Juni 2017 